\title{
Personal Branding And e-Professionalism
}

Chris Ward, University of Findlay, USA

Dan Yates, University of Findlay, USA

\begin{abstract}
As early as the late 1990's, Tom Peters started the conversation about personal branding with his book "The Brand Called You". This concept is not without its supporters and critics. Often people view personal branding as something negative such as bragging or possible view it as selfpromotion. In the world of Facebook, Twitter and LinkedIn, it is more important than ever that everyone, but primarily students, understand the implication of their online postings but also consider the importance of crafting, promoting, and defending their personal brand.
\end{abstract}

Keywords: Personal Branding; e-Professionalism; Social Networking Sites

\section{DEVELOPING YOUR BRAND}

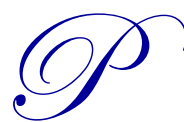

roost, Schreurs, Witte, \& Derous (2010) use a unique term called impression management. Impression management "refers to the activity of controlling information in an attempt to steer the impression others form of oneself in the service of personal or social goals" (p. 2156). The two tactics the authors determined which are often used during interviews are ingratiation and self-promotion. "Ingration tactics are used to evoke interpersonal attraction or liking, while self-promotion tactics are intended to draw attention to the positive qualities of oneself, one's future plans, or one's past accomplishments" (p. 2156). Both of these tactics can be effective if they are authentic and done with integrity. An article written by Hernez-Broome, McLaughlin, \& Trovas emphasize the importance of intentional and strategic self-promotion as well as maintaining ethical boundaries and being authentic. The authors admit that "self-promotion often gets a bad rap" (HernezBroome et al, 2009, p. 18) and is often labeled as brownnosing or sucking up. It is critical, however, to note that individuals who promote themselves often get promoted or other opportunities like special assignments. They outlined four techniques which people can benefit from if they are effectively deployed. First, self-promotion can enhance your career with promotions, increased responsibility, and additional visibility. Second, self-promotion techniques can help you stay motivated by developing additional skills or potentially getting recognized or rewarded for your contributions. Third, it can build credibility by having a reputation that aligns with accomplishments and it helps to make you a known commodity in your organization or community. Finally, self-promotion can also help you gain influence as other may view you as "effective, well-connected, powerful, knowledgeable, and up to date" (p. 20). For those who might be less inclined to self-promotion, Hernez-Broome, et al (2009) can have potential negative results such as no recognition $=$ no reward, unseen $=$ unknown, poor information $=$ poor decisions and less visible $=$ more vulnerable . You could miss out on opportunities, be disconnected from the organization's goals, be less inclined to be part of the decision-making process, and possibly be viewed as dispensable during difficult economic times.

\section{SOCIAL NETWORKING AND PERSONAL BRANDING}

Developing your footprint on the internet takes time, focus and is an important part of managing your career path. Plus, Groskop (2008) indicated "Everyone from a potential employer to a prospective blind date can check out our brand online" (p. 28). In fact, noted Brown \& Vaughn (2011), social networking sites (SNSs) such as Facebook, MySpace, and Twitter, and LinkedIn are often used by hiring managers to learn more about job candidates. While the legality of this practice is still unresolved, it is important to know that an increasing number of employers are searching social networking sites for postings or pictures that may provide insight into a candidate's character and professionalism. In fact, in a 2009 survey done by CareerBuilder, found that $45 \%$ of employers used social networking sites to research candidates. This was an increase of $22 \%$ from 2008 and that percentage was expected to go up by as much as $11 \%$ in 2010 (Grasz, 2009). LinkedIn, with its ability to provide 
recommendations from coworkers or previous employers and join professional groups, potentially provides the best social networking marketing tool. Burdick (2010) believes that "well-managed social networking is the key to your next career move, whether it's in your own company, to another company or starting your own business" (p. 30). She outlined four underlying social networking principles which can be used for business or career development. The first principle is to manage your strategy by finding "the venues that allow you to target the audiences you need to be in front of for business and career development" (p. 30). Secondly, she suggested, is to create differentiation. Just like products or services, develop the value proposition of your personal brand. Sills (2008) supports this premise and recommends developing your own hook by "sending clear signals regarding key attributes" (p. 63). Depending on the industry or position, these might include creativity, delivering on time, being a critical thinker or problem solver, or even the ability to work within a budget but most importantly, don't let the job title or position define you. Third on Burdick's list of principles is avoiding being a commodity. You want to compete on value, not price. As employers used social networking sites such as LinkedIn to find new employees, make sure your story is consistent so avoid being one of the crowd. The fourth and final principle is to build brand distinction. The comments you post, discussions you participate in, and the professional network you build not only expands your network but might just be a reference to your next job.

Social networking, though, does not come without some drawbacks especially for young people. MySpace and Facebook are often used by teens and young adults to express their individuality and form an identity. While often viewed as anonymous by these groups, this is hardly the case. Profiles on these sites are described by Salimkhan, Manago, and Greenfield (2010) as "digital descriptions of users, including for example, their interests, favorite movies, relationship status, and occupation" (p. 2). Users of these sites can quickly accumulate 'friends' and may not be able to control comments or pictures posted by others. As we teach students the value of promoting and protecting their personal brand, it is crucial to discuss the long term impact of social networking sites on their personal and professional identity. In a recent questionnaire done by Cain, Scott, \& Akers (2009) found 84.8\% of student reported that the image they presented online through Facebook accurately presented who they were as a person but only $65.2 \%$ believed their Facebook profile accurately presented who they were as a professional. Surprisingly, only $42.6 \%$ thought an employer should consider the profile information when making a hiring decision. This indicates a good opportunity to advise and coach students regarding their e-professionalism and what it could mean to future job opportunities. In an article by Maes and Farris (1998), they suggest students develop a marketing plan as well as a personal SWOT (strengths, weaknesses, opportunities and threats). The authors emphasized that students should start early in their planning process as they felt too many students waited too close to graduation to begin searching for a job. By using the 4P's of marketing (price, product, place and promotion), students can understand the relationship between the skills they develop and the potential price (salary) they might be able to negotiate; how to differentiate themselves with both tangible and intangible skills and capabilities; consider how geographic segmentation (where they are willing to live) as well as demographic segmentation (the size and type of industry they would like to work in) affects their long-term potential; and finally how they can develop an effective promotional plan to accomplish these goals. Often times, this means practicing some due diligence and restraint with one's online profile.

\section{FINAL THOUGHTS}

It is important, however, when developing your online and offline brand, including your leadership brand, to do it with integrity, authenticity, and consistency. Hernez-Broome, McLaughlin, \& Trovas (2007) said "Think of effective self-promotion in terms of strategic visibility, meaning that leaders are intentional in the way they publicize, what they share, and how they communicate" (p. 13). Furthermore, "when approached with authenticity and integrity, self-promotion helps leaders to build the valuable social capital needed to accomplish business outcomes" (p. 13). Wallis (2007) stated "Do this consistently and you will create an effective and powerful brand" (p. 64).

Acclaimed leadership author Tom Peters suggests identifying the qualities or characteristics that make you distinctive from your competitors or colleagues. Ask yourself the following questions: What did I do this week to make myself stand out? What would co-workers say is your greatest strength? What do I do that adds value? What am I most proud of? While these will help to define your personal brand, he added that there are four things you must measure yourself against: 
1. You've got to be a great teammate and a supportive colleague

2. You've got to be an exceptional expert at something that has real value

3. You've got to be a broad-gauged visionary - a leader, a teacher, a farsighted "imaginer"

4. You've got to be a businessperson - you've got to be obsessed with pragmatic outcomes (p. 7).

Without those four minimum foundational characteristics, building a positive brand may prove difficult.

While some people may still view self-promotion negatively, Burdick (2010) suggest thinking of "personal branding as performing regularly scheduled maintenance on your career" (p. 31). This may require you to step back, listen and get some advice from a mentor as well as taking the time on an annual or semi-annual basis to reflect on your accomplishments but also to determine if you are spending your time in the right areas and to possibly reposition yourself for those opportunities in the future. For institutions of higher education, Cain, et al (2009) felt that alongside traditional professional instruction, such as how to dress appropriately, interview techniques and resume writing, “... e-professionalism training and reinforcement may be required in this new digital age to address areas of concern with regard to online personas" (p. 5). Further research should address these concerns as educators may want to incorporate e-professionalism into their curricula, Career Services may want to include eprofessionalism in their discussions with students who are seeking internships and jobs, and employers should stay abreast of the legal implications of using social networking sites to screen employees.

\section{AUTHOR INFORMATION}

Dr. Ward is an Associate Professor of Business with The University of Findlay. Professor Ward brings her expertise from two Fortune 500 companies into the classroom teaching marketing and research. Professor Ward holds the following degrees: University of Sarasota, EdD, Organizational Leadership; MBA and Bachelor of Science in Business Administration from The University of Findlay. She is also a Six Sigma Black Belt, a 2008 and 2010 Ohio Partnership for Excellence Examiner, and NxLevel Instructor Certification and Six Disciplines coach. Her areas of research include student engagement, undergraduate research, small business marketing, and personal branding. Dr. Chris Ward, University of Findlay, 1000 North Main Street, Findlay, OH 45840 USA. E-mail: cward@findlay.edu (Corresponding author)

Dan Yates is an assistant professor of business at The University of Findlay. His teaching interests include entrepreneurship, leadership, organization development, and business strategy. Yates holds a $\mathrm{PhD}$ degree in Management from Northcentral University. He also has a MBA from University of Dayton, a Master of Organization Development degree from Bowling Green State University, and a BS in Accounting from Tiffin University. He completed the NxLevel Certification Course for Instructor Certification for teaching business plans at the Innovation Center (Ohio University). He has 30 years industrial and governmental experience. Dr. Dan Yates University of Findlay, 1000 North Main Street, Findlay, OH 45840 USA. E-mail: yates@ @indlay.edu

\section{REFERENCES}

1. Brown, V. R. \& Vaughn, E.D. (2011). The Writing of the (Facebook) Wall: The Use of Social Networking Sites in Hiring Decisions. Journal of Business Psychology, 26, 219-225.

2. $\quad$ Burdick, B. (January 2010). Social Graces. Quality Progress, 29-33.

3. Cain, J., Scott, D.R. \& Akers, P. (2009). Pharmacy Students' Facebook Activity and Opinions Regarding Accountability and E-Professionalism. American Journal of Pharmaceutical Education, 73(6), 1-6.

4. Kerfoot, K. (2004). On Leadership: Creating Your Own Leadership Brand. Urologic Nursing, 53(4), 438440.

5. Grasz, J. (2009). Forty-five Percent of Employers Use Social Networking Sites to Research Job Candidates, CareerBuilder Survey Finds. Retrieved September 8, 2012 from http://www.careerbuilder.com/share/aboutus/pressreleasesdetail.aspx $? \mathrm{id}=\mathrm{pr} 519 \& \mathrm{sd}=8 / 19 / 2009 \& \mathrm{ed}=12 / 31 /$ $\underline{2009}$

6. $\quad$ Groskop, V. (11 August 2008). Brand me! New Statesman, 28-29.

7. Hernez-Broome, G., McLaughlin, C., \& Trovas, S. (January/February 2007). Spreading the Word How to Self-Promote with Integrity. LIA, 26(4), 12-16. 
8. Hernez-Broome, G., McLaughlin, C., \& Trovas, S. (September/October 2009). Showcasing Your Talent with Authenticity. LIA, 29(4), 18-22.

9. Maes, J. D., \& Farris II, M. T. (1998). Teaching Students to Market a \$5.3 Million Asset: Themselves. Education + Training, 40(9), 405-410.

10. Peters, T. (1997). The Brand Called You. Retrieved on August 27 from http://www.fastcompany.com/28905/brand-called-you

11. Proost, K., Schreurs, B., Witte, K. D., \& Derous, E. Ingratiation and Self-Promotion in the Selection Interview: The Effects of Using Single Tactic or a Combination of Tactics on Interviewer Judgments. Journal of Applied Social Psychology, 40(9), 2155-2169.

12. Salimkhan, G., Manago, A., \& Greenfield, P. (2010). The Construction of the Virtual Self on MySpace. CyberPsychology: Journal of Psychosocial Research on Cyberspace, 4(1), 1-18.

13. Sills, J. (2008). Becoming Your Own Brand. Psychology Today, 62-63.

14. Wallas, L. (Jan/Feb 2007). Promote Brand You. Nursing Standard, 22(10), 64. 